\title{
IMPLEMENTASI ALGORITMA BRUTE FORCE DALAM APLIKASI KAMUS ISTILAH KESEHATAN
}

\author{
Heny Pratiwi ${ }^{1)}$, Ita Arfyanti ${ }^{2)}$, Dendy Kurniawan ${ }^{3)}$ \\ ${ }^{1}$ Teknik Informatika, STMIK Widya Cipta Dharma \\ ${ }^{2}$ Sistem Informasi, STMIK Widya Cipta Dharma \\ ${ }^{3}$ Teknik Informatika, STMIK Widya Cipta Dharma \\ 1,2,3 Jl. M. Yamin No.25, Samarinda, 75123 \\ E-mail : $\underline{\text { henypratiwi@gmail.com }}$, , qonita23@yahoo.com ${ }^{2)}$, dendykurniawan65@ yahoo.co.id ${ }^{3)}$
}

\begin{abstract}
Abstrak
Kamus merupakan alat bantu yang digunakan untuk menterjemahakan suatu bahasa, adapun terdapat berbagai jenis kamus seperti kamus istilah kesehatan. Kesehatan pada dasarnya penting dimiliki oleh setiap orang, namun masih banyak orang yang kurang memahami arti sebuah kesehatan, terutama istilah kesehatan yang memilik banyak kosa kata.

Penelitian dilakukan untuk dapat merancang suatu aplikasi kamus istilah kesehatan dengan menggunakan algoritma brute force dalam proses pencariannya. Algoritma brute force merupakan algoritma yang digunakan untuk mencocokan pattern dengan semua teks yang ada pada database aplikasi kamus istilah kesehatan. Dalam penelitian ini metode pengembangan sistem yang digunakan yaitu model prototype dan perangkat lunak pendukung yang digunakan adalah Microsoft Visual Studio 2012, dan Microsoft SQL Server. Adapun hasil akhir dari penelitian ini yakni berupa aplikasi kamus istilah kesehatan dengan menggunakan algoritma brute force dalam proses pencariannya dan dapat membantu pengguna untuk mencari istilah kata menjadi lebih efisen dibandingkan kamus berbentuk buku pada umumnya.
\end{abstract}

Kata kunci : Kamus, Algoritma, Brute Force, Kesehatan
Abstract
Dictionary is a tool that used for translate a language. There are many types of dictionary such as dictionary of health terms. Healthy basically is important for everyone, but there are still many people do not understand the meaning of a health.

Especially the health terms that has many unfamiliar vocabularies.

The research is conducted to design an application of health terms dictionary which use brute force algorithm for it searching process. Brute force algorithm is an algorithm that used to match pattern with all the text in application of health terms database.

The research was conducted at Kebaktian's medical store Samarinda. Data collection method used was like the interview that asked some questions relating to the design application process. In this research for system development methods used prototype mode. And than for software used Microsoft Visual Studio 2012, and Microsoft SQL Server.

The result of this research is an application of health term dictionary with brute force algorithm for searching system process and can help users to searching the terms with more efficient than the common dictionary.

Keywords: Dictionary, Brute Force Algorithm, Health.

\section{Pendahuluan}

Kamus merupakan sejenis buku acuan yang tersusun berdasarkan abjad dan berisi tentang istilahistilah beserta maknanya. Kamus sangat dibutuhkan dalam dunia pendidikan untuk mencari kata atau istilah yang ingin diketahui maknanya. Dalam dunia pendidikan banyak ditemukan istilah-istilah yang digunakan, misalnya dalam bidang kesehatan. Kesehatan pada dasarnya penting dimiliki oleh setiap orang, namun demikian banyak manusia dalam 
aktifitas hidupnya masih kurang peduli dengan nilai sebuah kesehatan. Mungkin masih banyak orang yang kurang memahami arti sebuah kesehatan, terutama istilah kesehatan yang memilik banyak kosa kata. Pada saat ini, dalam bidang kesehatan terdapat kamus berbentuk fisik yang memilki banyak kosa kata dengan susunan abjad dari A-Z, untuk mencari kosa kata yang diinginkan masih terdapat kesulitan dalam proses pencariannya karena kamus-kamus tersebut berukuran besar dan tebal sehingga waktu yang diperlukan dalam proses pencarian menjadi lama dan tidak efektif. Oleh sebab itu, dibuat suatu aplikasi kamus berbasis desktop yang bisa digunakan dengan secara lebih efesien dalam mencari istilah kata pada kamus yang sebenarnya. Pada penelitian ini dirancang dengan menggunakan algoritma string matching. Algoritma string matching merupakan suatu algoritma yang digunakan untuk masalah pencocokan suatu teks terhadap teks lain dan algoritma string yang digunakan adalah algoritma brute force.

Batasan masalah pada penelitian ini adalah tentang implementasi algoritma brute force dalam aplikasi kamus istilah kesehatan yang berbasis dekstop. Kosa kata pada aplikasi kamus ini meliputi istilah kosa kata seputar kesehatan, nama-nama penyakit, organ tubuh manusia, dan obat-obatan. Masing-masing istilah kosa kata dibatasi di setiap alphabetical dengan sepuluh inputan kata per alphabet. Kosa kata yang dicari hanya akan menampilkan istilah secara definisi ataupun keterangan seperti kamus pada umumnya.

Tujuan penyusunan penelitian ini adalah untuk menerapkan algoritma brute force dalam perancangan aplikasi kamus istilah kesehatan yang akan dibuat dan juga dalam merancang perangkat lunak ini untuk menjadi aplikasi rujukan kamus istilah kesehatan berbasis desktop yang bisa digunakan secara offline sehingga nantinya dapat mempermudah mahasiswa di bidang kesehatan maupun orang awam dalam mencari istilah atau kata yang diinginkan dengan lebih efesien atau tanpa perlu lagi membuka perlembar dan membawa kamus Ilmu kesehatan secara manual.

\section{KAJIAN LITERATUR}

Teori yang dikaji untuk digunakan dalam penelitian, meliputi algoritma, algoritma Brute Force, aplikasi.

\section{II.1 Algoritma}

Istilah algoritma berasal dari nama seorang pengarang berkebangsaan Arab bernama Ja'fat Mohammed bin Musa al Khawarizmi tahun (790 840), yang sangat terkenal dengan sebutan bapak Aljabar. Secara defenisi algoritma adalah alur pemikiran yang logis yang dapat dituangkan ke dalam bentuk tulisan. Sebuah algoritma dikatakan benar (correct) jika algoritma tersebut berhasil mengeluarkan output yang benar untuk semua kemungkinan input (Yogiyanto, 2005).

\section{II.2 Algoritma Brute Force}

Algoritma brute force adalah algoritma yang digunakan untuk mencocokan pattern dengan semua teks antara 0 dan n-m untuk menemukan keberadaan Pattern teks. Algoritma brute force memecahkan masalah dengan sangat sederhana, langsung, dan jelas. Algortima brute-force merupakan suatu teknik yang biasa digunakan bila si penyusun algoritma lebih mempertimbangkan memperoleh solusi dari problem secara langsung apa adanya (Sarno, 2012). Secara rinci langkah-langkah yang digunakan algoritma brute force untuk mencocokkan string adalah, sebagai berikut:

1. Algoritma brute force mulai mencocokan pattern dari awal teks.

2. Dari kiri ke kanan, algoritma brute force akan mencocokan karakter per karakter pattern dengan karakter pada teks yang bersesuaian, sampai salah satu kondisi berikut terpenuhi :

a. Karakter di pattern yang dibandingkan cocok maka pencarian selesai.

b. Apabila dijumpai ketidak cocokan antara pattern dengan teks, maka pencarian tidak cocok dan belum berhasil.

3. Kemudian algoritma brute force terus menggeser pattern sebesar satu ke kanan, dan mengulangi langkah ke-2 sampai pattern berada di ujung teks. Seperti halnya dengan algoritma lainnya, algoritma brute force juga mempunyai kelebihan dan kekurangan. Kelebihan brute force adalah :

a. Algoritma brute force dapat digunakan untuk memecahkan hampir dari sebagian masalah.

b. Algoritma brute force sederhana dan mudah dimengerti.

Sedangkan kelemahan dari algoritma brute force adalah, sebagai berikut:

a. Tidak sekontruktif teknik pemecahan masalah lainnya. 
Adapun pseucode dari pencarian algoritma brute force, yaitu:

Procedure Algoritma

Input :

$m, n$ sebagai lenght dari pattern dan teks

$x$ sebagai pattern

y sebagai teks

proses

perulangan $i=0$ ke $m-n$ maka

$j=0$

jika j lebih kecil dari $n$ dan

$x$ [ i ditambah 1] $=y$ [j]

maka

$j=j$ ditambah 1

akhir jika

jika j lebih besar sama

dengan $n$

maka

pattern= benar (ditemukan)

akhir jika

akhir perulangan

output :

pattern ditemukan.

\section{II.3 Aplikasi}

Perangkat lunak aplikasi adalah program yang ditulis dan diterjemahkan oleh language software untuk menyelesaikan suatu aplikasi tertentu. Aplikasi juga merupakan program siap pakai yang digunakan manusia dalam melakukan pekerjaan dengan menggunakan komputer. (Rahmat, 2010).

\section{II.4 Kamus}

Menurut WJS Poerwadarminta (2005) Kamus adalah buku berisi keterangan tentang arti kata-kata. Sedangkan menurut Hoetomo M.A (2005) mendefinisikan, kamus yaitu buku acuan yang memuat kata dan ungkapan yang biasanya disusun menurut abjad berikut keterangan dan maknanya. Dari definisi kamus diatas dapat disimpulkan bahwa kamus merupakan buku yang membuat kumpulan istilah atau nama-nama yang disusun beserta penjelasannya tentang pemakaiannya, disusun menurut abjad berikut keterangan maknanya, atau terjemahannya dari istilah atau nama-nama tersebut.

\section{II.5 Kesehatan}

Menurut Hasan dalam Kamus Besar Bahasa Indonesia (2005), sehat adalah keadaan seluruh badan serta bagian-bagiannya bebas dari sakit. Menurut UU kesehatan No 23 tahun 1992, sehat adalah keadaan sejahtera dari badan,jiwa, dan sosial yang memungkinkan setiap orang hidup produktif secara sosial dan ekonomis.

Menurut Badan Kesehatan Dunia World Health Organization (WHO), sehat adalah keadaan sejahtera secara fisik, mental, dan sosial yang terbebas dari suatu penyakit sehingga seseorang dapat melakukan aktivitas secara optimal. Dapat disimpulkan dari keterangan diatas bahwa kesehatan adalah suatu hal yang bersifat dalam keadaan sejahtera secara fisik, mental dan sosial yang terbebas dari penyakit.

\section{Metode Penelitian}

Dalam mengembangkan aplikasi ini, metode yang digunakan adalah model prototipe (prototype). Menggunakan model ini karena aplikasi yang dibuat yaitu aplikasi kamus istilah kesehatan dalam perancangannya antara developer dan user harus saling berkaitan, terlebih di dalam proses input istilah kosa kata dan definisinya yang dimana apabila terdapat kekurangan ataupun penambahan istilah kosa kata baru yang ingin ditambahkan, user dapat memberi masukkan kepada developer dan developer pun harus mendengarkan, memperbaiki dan kemudian dipresentasikan kepada pelanggan sehingga perangkat lunak yang dihasilkan nantinya sesuai dengan kebutuhan pelanggan.

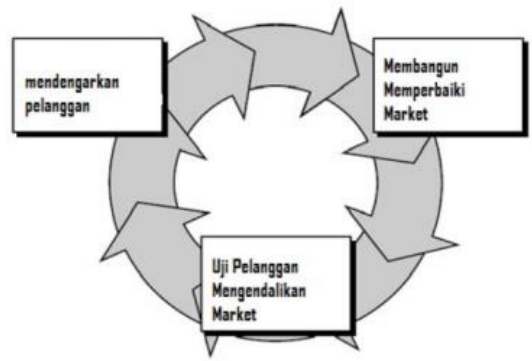

Gambar 1. Pendekatan Prototype

\section{III.1 Mendengarkan Pelanggan}

Pada tahap ini pelanggan dan pengembang bersama-sama mendefinisikan format seluruh perangkat lunak, mengindentifikasikan semua kebutuhan dan garis besar dari sistem yang akan dibuat dimana dapat dikatakan pula sebagai pengumpulan kebutuhan. Pengumpulan kebutuhan dapat di definisikan sebagai penguraian dari suatu 
sistem informasi yang utuh kedalam bagian-bagian komponennya. Dengan maksud untuk identifikasi dan evaluasi permasalahan-permasalahan, kesempatan, dan hambatan yang terjadi dan kebutuhan-kebutuhan yang diharapkan sehingga dapat diusulkan perbaikannya.

\section{III.1.1 Pengumpulan Kebutuhan Data}

Dalam pengumpulan kebutuhan data, hal-hal yang diperlukan yaitu beberapa data yang diperoleh dari buku-buku literatur, kamus yang ada di perpustakaan atapun berbagai macam sumber buku referensi lainnya yang berkaitan dengan proses perancangan aplikasi kamus istilah kesehatan.

\section{III.1.2 Pengumpulan Kebutuhan}

Pengumpulan kebutuhan merupakan analisis untuk mengetahui kebutuhan apa saja yang diperlukan dalam membuat implementasi algoritma brute force dalam aplikasi kamus istilah kesehatan baik itu dari segi perangkat lunak dan perangkat keras yang akan digunakan.

\section{III.2 Membangun Dan Memperbaiki Market}

Pada tahap ini dilakukan membangun suatu perancangan dan pembuatan prototype sistem. Prototype yang dibangun disesuaikan dengan kebutuhan sistem yang telah didefinisikan dan apabila nantinya terdapat perubahan dari pelanggan maka developer harus dapat memperbaiki prototype atau desain sistem sesuai dengan kebutuhan user.

\section{III.3 Implementasi}

Setelah melakukan pengumpulan kebutuhan dan perancangan sistem, maka dilakukan tahapan implementasi yaitu pembangunan aplikasi, dalam hal ini difokuskan pada pembuatan program dan penggunaanya, program yang dibangun pun langsung diuji dan dilihat apakah sudah bekerja dengan baik atau belum. Adapun bagian-bagian yang dibangun dalam pembuatan aplikasi kamus istilah kesehatan ini adalah:

1. Struktur database

2. Form Menu yang juga merupakan tampilan utama,

3. Form Login admin,

4. Form Admin,

5. Form Tambah Istilah,

6. Form Ubah Password,

7. Form Cari istilah,

8. Form Definisi, dan
9. Form Tentang Aplikasi.

\section{III.4 Uji Sistem}

Pada tahap ini prototype dari sistem diuji coba oleh pelanggan. Kemudian dilakukan evaluasi apabila terdapat kekurangan-kekurangan dari kebutuhan pelanggan untuk memperbaiki sistem yang ada.

Metode pengujian sistem yang digunakan pada perancangan implementasi algoritma brute force dalam aplikasi kamus istilah kesehatan ini adalah metode pengujian whitebox dan blackbox yang merupakan suatu metode pengecekan terhadap detail perancangan dan desain program.

\section{Black-box Testing}

Tujuan dari metode Black-Box Testing adalah untuk mendapatkan kesalahan output yang dihasilkan program sebanyak-banyaknya. Metode ini dilakukan dengan cara menjalankan atau mengeksekusi program yang dihasilkan. Kemudian diamati apakah hasil dari program tersebut sesuai dengan hasil yang diinginkan. Jika masih terdapat kesalahan atau terdapat hasil yang tidak sesuai dengan yang diinginkan, maka kesalahan ataupun ketidaksesuaian tersebut dicatat untuk selanjutnya diperiksa satu per satu dan diperbaiki.

White-box Testing

Pengujian ini pada umumnya didasarkan pada pengecekan terhadap detail perancangan dan kode program, menggunakan struktur kontrol dari desain program secara procedural untuk membagi pengujian ke dalam beberapa kasus pengujian. Secara sekilas dapat diambil kesimpulan white box testing merupakan petunjuk untuk mendapatkan program yang benar secara $100 \%$.

\section{HASIL DAN PEMBahasaN}

\section{IV.1 Implementasi Rancangan Sistem}

Di dalam merancang aplikasi kamus istiah kesehatan ini, digunakan alat bantu untuk mempermudah proses perancangan sistem. Perancangan sistem ini menggunakan diagram alir (flowchart).

\section{Flowchart Proses Tambah Istilah}

Flowchart proses tambah istilah merupakan suatu rancangan sistem yang digunakan untuk memperlihatkan alur dari kinerja sistem untuk melakukan proses tambah istilah pada aplikasi kamus istilah kesehatan. Flowchart ini dapat dilihat pada gambar 2. 


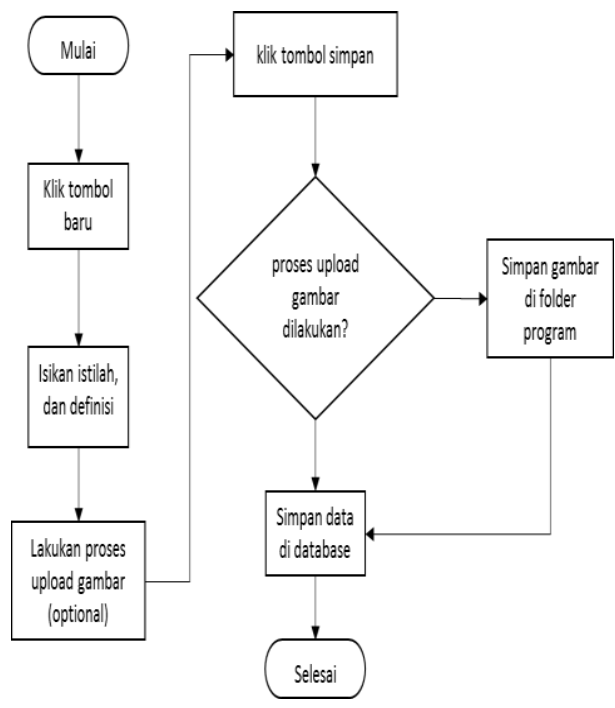

Gambar 2. Flowchart Proses Tambah Istilah

Pada flowchart sistem menjelaskan tentang alur proses tambah istilah pada aplikasi kamus istilah kesehatan. Pertama yaitu untuk menambah istilah dengan melakukan klik tombol baru pada sistem, setelah itu lakukan proses isikan istilah dan definisi lalu melakukan proses upload gambar apabila ingin di tambahkan gambar pada istilah yang baru di inputkan, klik tombol simpan, proses upload gambar dilakukan apabila ya maka akan melakukan proses simpan gambar dalam folder program serta juga proses menyimpan data di dalam database, dan apabila tidak melakukan proses upload gambar maka sistem akan langsung menyimpan data ke dalam database dan selesai.

\section{Flowchart Proses Pencarian Istilah}

Flowchart cari istilah menjelaskan tentang alur proses cari istilah pada aplikasi kamus istilah kesehatan. Cari, kata, string, frase, lenghtcari, dan lenghtkata adalah variabel yang digunakan dalam proses cari istilah pada aplikasi kamus istilah kesehatan. 'Cari' digunakan untuk menampung frase yang ingin dicari, 'kata' digunakan untuk menampung istilah di dalam database, 'frase' digunakan untuk menampung kelompok kata dari istilah yang dibandingkan (misal frase "dok" dari kata "dokter"), lenghtcari jumlah huruf dari variabel cari, dan lenghtkata adalah jumlah huruf dari variabel kata. Flowchart ini dapat dilihat pada gambar 3.

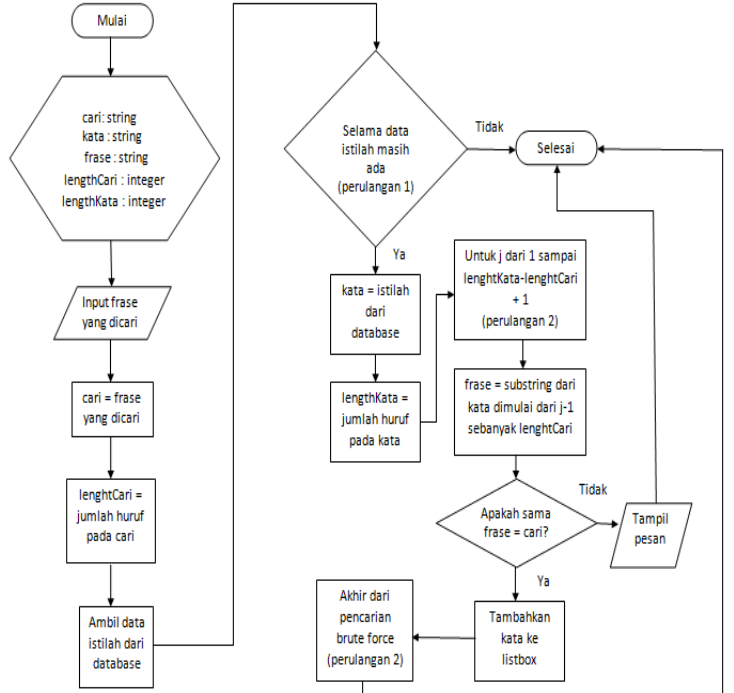

Gambar 3. Flowchart Proses Cari Istilah

Pertama dari proses alur yaitu inputkan frase kata yang akan dicari, proses cari dilakukan, pada variabel cari sama dengan frase yang dicari di dalam textbox, kemudian proses lenghtcari dilakukan, pada variabel lenghtcari sama dengan jumlah huruf yang ada pada variabel cari atau kata yang ingin dicari, kemudian alur flowchart dilanjutkan dengan proses ambil data istilah dari database, dan akan ada decision perulangan 1 yang merupakan perulangan untuk mencocokkan variabel cari untuk setiap variabel kata yang ada di tabel istilah selama data tabel istilah masih ada atau berkaitan. Apabila tidak sistem akan selesai sedangkan apabila ya maka dilakukan proses pencocokan variabel 'kata' dan lenghtkata lalu akan melakukan proses perulangan 2 yaitu perulangan pencocokan variabel 'cari' untuk variabel frase dari variabel 'kata', dan perulangan ini merupakan proses algoritma brute force itu sendiri. Kemudian sistem akan melakukan proses mencari frase yang dimana frase tersebut merupakan substring dari kata (istilah yang tersimpan di database). Adapun contoh algoritma brute force mencari frase pada sistem seperti, misal mencari frase "kte" pada textbox dari kata "dokter"(yang disimpan di dalam variabel kata atau database). Langkah 1 dari pencarian algoritma:

a. $\quad$ Frase $=$ "dok" (karena lengthCari $=3$, maka frase diambil dari 3 huruf awal dari variabel kata) langkah ini mengacu pada $\mathrm{j}=0$ untuk iterasi pertama. 
b. Bandingkan 'frase' dengan 'cari', apakah sama? Karena "dok" tidak sama dengan "kte", maka perulangan akan diteruskan.

Langkah 2 dari pencarian algoritma:

a. Frase = "okt". Ini merupakan 3 huruf berikutnya, yaitu frase yang dimulai dari j-1 dengan jumlah huruf lengthCari. Untuk iterasi $2, \mathrm{j}=2$, sehingga huruf yang digunakan dari mulai dari huruf ke-1 sebanyak 3 huruf (huruf pertama indeksnya adalah 0).

b. Bandingkan 'frase' dengan 'cari', apakah sama? Karena "okt" tidak sama dengan "kte", maka perulangan akan diteruskan.

Langkah 3 dari pencarian algoritma:

a. Frase = "kte"

b. Bandingkan 'frase' dengan 'cari', apakah sama? Karena "kte" sama dengan "kte", maka perulangan 2 untuk algoritma brute force dihentikan dan 'kata' akan ditambahkan ke dalam listbox dan selesai.

Apabila seandainya tidak ditemukan kecocokan antara 'frase' dan 'cari', maka akan ditampilkan pesan pada aplikasi dan perulangan untuk algoritma brute force berakhir 'kata' tidak di tambahkan ke listbox dan selesai.

Adapun penjelasan contoh lain untuk proses pencarian kata yang dilakukan algoritma brute force dalam mencocokan kata pada aplikasi yaitu, secara umum 'pattern' $(\mathrm{X})$ dilambangkan sebagai kata yang ingin dicari dan 'teks' (Y) dilambangkan sebagai kata yang tersimpan di dalam database. Pada implementasi algoritma brute force dalam aplikasi kamus istilah kesehatan 'pattern' memiliki fungsi sama dengan 'Cari' yang dilambangkan sebagai kata yang ingin dicari pada teks sedangkan 'teks' memiliki fungsi sama dengan 'Kata' yang merupakan variabel untuk dilambangkan sebagai kata atau istilah yang tersimpan di dalam database.

\section{IV.2 Implementasi Program}

Kamus istilah kesehatan yang telah dirancang merupakan aplikasi berbasis dekstop yang dapat digunakan secara offline. Dan dalam proses pecariannya menggunakan algoritma brute force yang merupakan pencocokan antara pattern dan teks. Berikut tampilan dari aplikasi kamus istilah kesehatan
Gambar 4 menampilkan form menu utama aplikasi. Form ini dapat diakses oleh semua pengguna aplikasi kamus istilah kesehatan. Pada form ini terdapat beberapa button pilihan yaitu "Cari Istilah", "Tentang Aplikasi", dan "keluar".

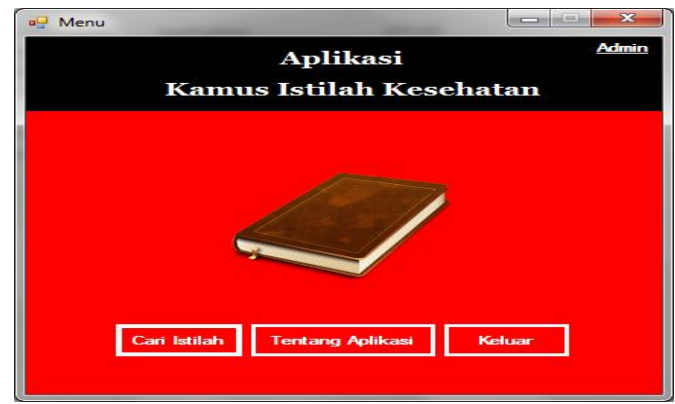

Gambar 4. Tampilan Menu Utama

Jika pengguna mengakses aplikasi sebagai administrator, maka pengguna dapat menambahkan istilah baru, dan mengubah password administrator. Gambar 5 adalah pilihan menu jika pengguna mengakses aplikasi sebagai administrator.

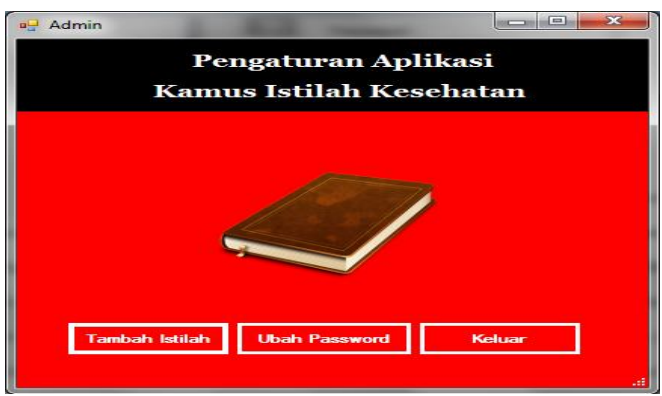

Gambar 5. Tampilan Form Admin

Jika aplikasi diakses oleh administrator, maka pengguna dapat menambahkan istilah baru melalui form Tambah istilah seperti pada gambar 6 .

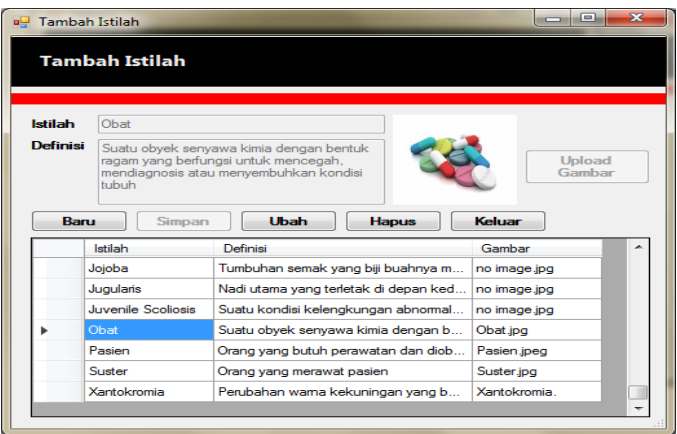

Gambar 6. Tampilan Tambah Istilah 
Hasil pengisian istilah kesehatan dapat diakses oleh pengguna melalui form pencarian istilah seperti pada gambar 7. Pada form ini, pencarian dilakukan dengan menerapkan algoritma brute force

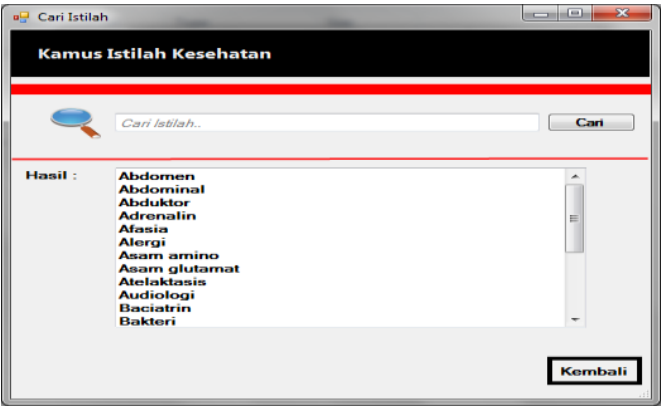

Gambar 7. Tampilan Cari Istilah

\section{KESIMPULAN}

Dengan adanya hasil penelitian yang dilaksanakan dan berdasarkan uraian yang telah dibahas pada uraian sebelumnya, maka dapat ditarik kesimpulan bahwa:

1. Algoritma Brute Force merupakan algoritma pencarian yang dapat diterapkan dalam perancangan aplikasi kamus istilah kesehatan sehingga dapat memudahkan bagi pegguna untuk mencari kata yang ingin diterjemahkan.

2. Aplikasi Kamus Istilah Kesehatan ini dibuat dan dikembangkan dengan menggunakan bahasa pemograman Visual Basic.Net dan telah berhasil merubah sistem manual ke dalam sistem komputer, sehingga memudahkan dalam hal mengolah dan mencari data.

\section{REFERENSI}

Jogiyanto,M. 2005. Analisa dan sistem informatika dan analisa dan sistem informasi. Yogyakarta. Andi offset.

Poerwadarminta. 2005. Kamus Umum Bahasa Indonesia. Jakarta: Balai Pustaka.

Rahmat. 2010. Algoritma dan Pemrograman dengan Bahasa C. Yogyakarta. Andi offset.

Sarno. 2012. Semantic Search Pencarian Berdasarkan Konten. Yogyakarta. Andi offset. 